\title{
Characterization of a $\gamma-3$ Proteobacteria Responsible for the Syndrome "Basses Richesses" of Sugar Beet Transmitted by Pentastiridius sp. (Hemiptera, Cixiidae)
}

\author{
Olivier Sémétey, Frédéric Gatineau, Alberto Bressan, and Elisabeth Boudon-Padieu
}

\author{
Biologie et écologie des Phytoplasmes, UMR PME, INRA 1088, CNRS 5184, Université de Bourgogne, INRA Domaine d'Epoisses, BP \\ 86510, 21065 Dijon cedex, France. \\ Current address of F. Gatineau: CIRAD, TA 80/A. Campus international de Baillarguet, 34398 Montpellier cedex 5, France. \\ Current address of E. Boudon-Padieu: INRA, UMR PME, BP 86510, 21065 Dijon cedex, France. \\ Accepted for publication 17 August 2006.
}

\begin{abstract}
Sémétey, O., Gatineau, F., Bressan, A., and Boudon-Padieu, E. 2007. Characterization of a $\gamma-3$ proteobacteria responsible for the syndrome "basses richesses" of sugar beet transmitted by Pentastiridius sp. (Hemiptera, Cixiidae). Phytopathology 97:72-78.

The disease syndrome "basses richesses" (SBR) has affected sugar beet crops in Burgundy (France) since 1991. It mainly is associated with an uncultivable phloem-restricted bacterium-like organism (BLO) called SBR BLO. Transmission tests showed that field-collected Pentastiridius sp. (Hemiptera, Cixiidae) were able to transmit the SBR BLO to sugar beet. In the present work, sequences of a 1,507-bp 16S ribosomal (r)DNA fragment of SBR BLO were amplified from DNA extracts of SBR-

hoppers, and of Pentastiridius sp.-exposed sugar beet seedlings that expressed SBR symptoms. The sequences showed total identity, confirming the role of SBR BLO in the etiology of SBR and the vector role of Pentastiridius sp. Our surveys on SBR-affected sugar beet plants and Pentastiridius sp. planthoppers collected in different fields and different years suggest that a unique BLO was involved in SBR. Furthermore, comparison of $16 \mathrm{~S}$ rDNA sequences permitted the identification of the SBR BLO as a new plant-pathogenic $\gamma-3$ proteobacteria different from 'Candidatus Phlomobacter fragariae,' another BLO responsible for marginal chlorosis disease of strawberry in France. Phylogenetic analysis revealed a close relationship between the SBR bacterium and several bacteria described as endosymbionts of hemipteran insects.
\end{abstract} affected field sugar beet plants, of field-collected Pentastiridius sp. plant-
The disease of sugar beet known as the syndrome "basses richesses" (SBR) repeatedly has affected sugar beet crops in the Burgundy and Jura regions of Eastern France since 1991 (18). SBR symptoms appear in late summer shortly before harvest. Visual symptoms are deformation and discoloration of leaves and a brownish discoloration of taproot vascular tissue. Overall, SBR causes a loss of taproot sugar content which can have dramatic economic consequences for growers and the local sugar beet industry; in 1991, the loss of income was $\approx 50 \%$ over 1,000 ha (18); in 2004, the rate of affected plants in plots was 15 to $100 \%$ over 1,800 ha. Studies using molecular diagnostic, microscope observations, and transmission experiments with candidate insect vectors have provided some clues to the epidemiology and etiology of the disease (13). In 1999, a planthopper of the genus Pentastiridius (Hemiptera, Cixiidae) (13), found to be abundant in sugar beet crops, was suspected as a vector of the disease because a large number of plants exposed to wild planthoppers of Pentastiridius sp. exhibited similar symptoms to those of SBR. A predominant bacterium-like-organism (BLO), here referred to as SBR BLO, and a stolbur phytoplasma were visualized and detected in field-collected SBR-affected sugar beet plants and Pentastiridius sp.-exposed symptomatic sugar beet seedlings (12). These results strongly suggested that both phloem-inhabiting organisms were agents responsible for SBR symptoms and both were transmitted by Pentastiridius sp., although only the stolbur phytoplasma could be detected in Pentastiridius sp. (13). Symp-

Corresponding author: E. Boudon-Padieu: E-mail address: boudon@epoisses.inra.fr

DOI: 10.1094/PHYTO-97-0072

(C) 2007 The American Phytopathological Society toms associated with the BLO or with the phytoplasma are similar at the macroscopic level but different at the histological level (13).

The BLO associated with SBR-affected plants from the field and insect-exposed plants could not be cultivated despite several attempts (F. Gatineau, unpublished data). They could be detected in plants with PCR using the primer pair Fra5-Fra4 (12). These primers previously were designed for amplification of $16 \mathrm{~S}$ ribosomal (r)DNA of 'Candidatus Phlomobacter fragariae', a BLO of the $\gamma-3$ proteobacteria subgroup which is a phloem-restricted pathogen associated with marginal chlorosis of strawberry in France and is transmitted by the cixiid Cixius wagneri (China) (Hemiptera, Cixiidae) $(6,7,27)$.

In the present work, we compared BLO detected in SBRaffected sugar beet plants from the field, in Pentastiridius sp.exposed sugar beet plants, and in feral Pentastiridius sp. and 'Candidatus Phlomobacter fragariae' on the basis of sequences of polymerase chain reaction (PCR)-amplified 16S rDNA $(24,27)$ and of a non-rDNA region (10). A phylogenetic analysis of $16 \mathrm{~S}$ rDNA also was conducted to characterize the SBR BLO, a new plant-pathogenic $\gamma$-3 proteobacteria.

\section{MATERIALS AND METHODS}

Plants and insects. Sugar beet (Beta vulgaris L.) plants showing SBR symptoms were uprooted in Jura and Burgundy in SBRaffected fields in 2000. Plants from the same field without symptoms also were harvested. The healthy negative control consisted of sugar beet seedlings grown in the greenhouse. Sugar beet seedlings from SBR transmission assays also were examined. A positive control for the presence of 'Candidatus Phlomobacter fragariae' consisted of a strawberry (Fragaria vesca L.) plant 
affected by marginal chlorosis disease (kindly provided by CIREF, Lanxade, France).

Pentastiridius sp. planthoppers were trapped during the flight activity of adults (June and July) by using a D-Vac aspirator in sugar beet crops severely affected by SBR in Jura in 2000 and 2002 and in Burgundy in 2004.

Transmission assays of SBR. Transmission to sugar beet by field-collected Pentastiridius sp. planthoppers was performed in a growth chamber $\left(23 \pm 1^{\circ} \mathrm{C}, 16 \mathrm{~h}\right.$ of light and $8 \mathrm{~h}$ of darkness $)$ by confining 1 to 20 insects per sugar beet seedling for an inoculation access period (IAP) of 1 to 7 days. Upon completion of each IAP, insects were collected and inoculated sugar beet plants were sprayed with Dichlorvos (Bayer) at $0.5 \mathrm{~g} /$ liter and transported to an insect-proof greenhouse $\left(26 \pm 5^{\circ} \mathrm{C}\right.$, natural light) until expression of SBR symptoms.

Total DNA extraction from plants and insects. Total DNA was extracted from $1 \mathrm{~g}$ of vascular tissue excised from the taproot of sugar beet plants, from petioles of strawberry, and from individual Pentastiridius sp. planthoppers with cetyltrimethyl ammonium bromide (CTAB) buffer as previously described (13).

Phytoplasma detection. All plants and Pentastiriudius sp. specimens were checked for phytoplasma infection using nested PCR amplification of phytoplasma 16S rDNA with two generic primer pairs (13). Incidence of phytoplasma was low (13). Only negative samples were used for molecular detection of SBR BLO DNA.

PCR assays. PCR amplification was done according to three different procedures. Assays were performed in 40- $\mu$ l reaction mixtures. In two procedures, fD1 and rP1 primers (24) were used in combination with primers Fra5 and Fra4, respectively (27). fD1 and $\mathrm{rP} 1$ are universal primers for amplification of the 16S rRNA gene of bacteria (24). The fD1-Fra4 and Fra5-rP1 fragments of 16S rDNA overlap by the common Fra5-Fra4 sequence (27). All primer pairs were used at $1.0 \mu \mathrm{M}$ in a reaction mixture containing $200 \mu \mathrm{M}$ each dNTP, $78 \mathrm{mM}$ TrisHCl at $\mathrm{pH} 8.4,5 \mathrm{mM} \mathrm{MgCl}_{2}$, $0.1 \%$ Triton X-100, bovine serum albumin (BSA) at $200 \mu \mathrm{g} / \mathrm{ml}$, 2 units of Taq DNA polymerase (Q. BIOgene, Illkirch, France), and $150 \mathrm{ng}$ of target DNA. PCR reactions were carried out in a Biometra thermocycler as follows: 8 cycles with denaturation for $45 \mathrm{~s}$ at $92^{\circ} \mathrm{C}$, annealing for $30 \mathrm{~s}$ at $58^{\circ} \mathrm{C},-0.5^{\circ} \mathrm{C}$ per cycle, and elongation for $60 \mathrm{~s}$ at $72^{\circ} \mathrm{C}$, followed by 27 cycles of denaturation for $45 \mathrm{~s}$ at $92^{\circ} \mathrm{C}$, annealing for $30 \mathrm{~s}$ at $54^{\circ} \mathrm{C}$, and elongation for $60 \mathrm{~s}$ at $72^{\circ} \mathrm{C}$. The amplification program was ended by $10 \mathrm{~min}$ at $72^{\circ} \mathrm{C}$. In a third PCR procedure, total DNA was PCR amplified using the primer pair Pfr1-Pfr4, designed from a cloned fragment of a 'Candidatus Phlomobacter fragariae' open reading frame. According to Foissac et al. (10), this fragment shares identity with the spoT gene from other proteobacteria, such as Escherichia coli. The gene spoT encodes ppGppase, an enzyme involved in a basic cellular process (10). Reaction mixture and PCR conditions were as previously described (10).

Analysis of PCR products. PCR products $(7 \mu \mathrm{l})$ were analyzed by electrophoresis in $1.2 \%$ agarose gels, stained with ethidium bromide, and visualized under UV light. The expected size of fD1-Fra4, Fra5-rP1, and Pfr1-Pfr4 amplicons were 976, 1,040, and 895 bp, respectively.

Molecular comparisons. For molecular comparisons, we selected samples that tested, by PCR, negative for phytoplasma and positive with fD1/Fra4 and Fra5/rP1 primer pairs (Table 1). The presence of BLO in the phloem of SBR-affected sugar beet plants and 'Candidatus Phlomobacter fragariae'-infected strawberry plants was verified using 4'-6-diamidine-2-phenyl indole (DAPI) staining with UV light microscopy (12). All plants that tested positive for the presence of a BLO with DAPI staining also tested positive by PCR with fD1/Fra4 and Fra5/rP1 primer pairs.

Sequencing and nucleotide sequence analysis. fD1-Fra4 and Fra5-rP1 amplicons obtained from symptomatic plants and a Pentastiridius sp. specimen shown in Table 1 were excised individually from the agarose gel, solubilized by several successive thawing and freezing cycles (from $-20^{\circ} \mathrm{C}$ to room temperature) in $100 \mu \mathrm{l}$ of buffer (10 mM Tris, $1 \mathrm{mM}$ EDTA, $\mathrm{pH} 8$ ), and each reamplified with the same procedure. Resulting PCR products were directly sequenced by MWG AG Biotech (Ebersberg, Germany). For each plant, nucleotide sequences from overlapping fD1-Fra4 and Fra5-rP1 fragments were merged to obtain the fD1-rP1 sequence using CLUSTAL W 1.8 Multiple Sequence Alignment (version 1.8; from the EBI) (15). The fD1-rP1 sequences obtained from plant and insect samples were submitted to a multiple sequence alignment analysis using the CLUSTAL W program. Orthologous sequences from other organisms were obtained from the GenBank Database using EBI BLAST2 (1).

Phylogenetic study. Phylogenetic analysis of the $16 \mathrm{~S}$ rDNA sequences of SBR-BLO and of bacteria representative of a $\gamma-3$ proteobacteria was performed using CLUSTAL W Multiple Sequence Alignment Program and included the 16S rDNA sequences of SBR-BLO and of bacteria representative of $\gamma$-proteobacteria. A phylogenetic tree was constructed based on the phylogenetic analysis results using MEGA 2 program (version 2.1) (19). Tree construction was performed by the neighbor-joining method. Numbers at nodes represented bootstrap percentages based on 1,000 replications; only nodes supported by $85 \%$ or higher are shown. The tree was made with the following options. For removal of gaps and missing data, distance was calculated by the Kimura 2-parameter method. 'Candidatus Portiera aleyrodidarum' (AY268082) was used to root the phylogenetic tree. Most of the bacteria with high sequence homology found in GenBank were associated with insect hosts. This tree was associated with an evolutionary framework of Hemiptera hosts of bacteria based on a composite of current inferences including molecular and morphological interpretations (4).

Accession numbers of proteobacteria used for phylogenetic analysis. In addition to the accession numbers given in Table 2, other $\gamma$-proteobacteria used were as follows: bacterial parasite of Euscelidius variegatus (Z14096), Baumannia cicadellinicola (AF489427) endosymbiont of Homalodisca coagulata (sharp-

TABLE 1. Plant and insect material used for molecular study

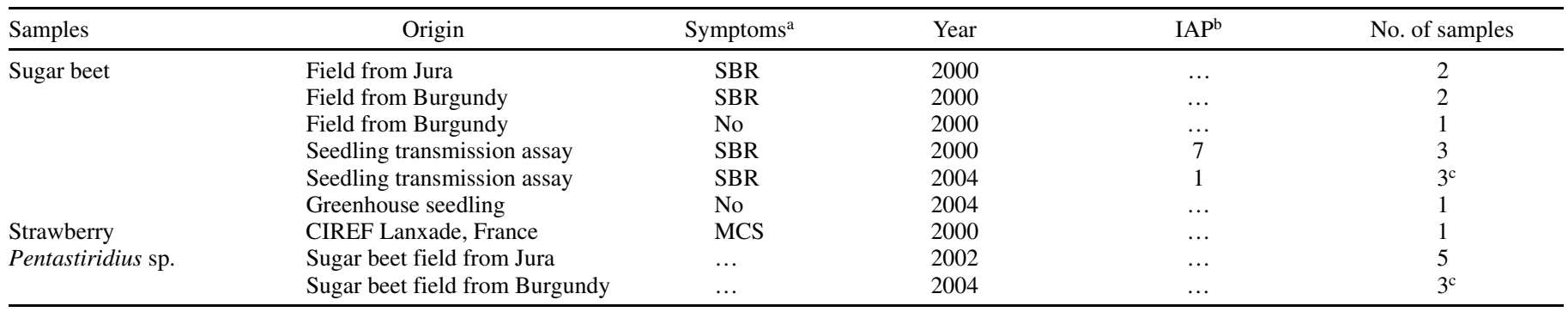

a SBR = symptoms of syndrome "basses richesses" and MCS = symptoms of marginal chlorosis of strawberry.

${ }^{\mathrm{b}}$ Inoculation access period (days).

${ }^{c}$ Plants were inoculated with the corresponding insects. 
shooters), 'Candidatus Blochmannia floridanus' (X92549) endosymbiotic bacteria of Camponotus spp. (carpenter ant), 'Candidatus Carsonella ruddii' (AF211143), 'Candidatus Portiera aleyrodidarum' (AY268082), Cimex lectularius endosymbiont (bedbug) (U65654), Escherichia coli (AB045731), Haemophilus influenzae (AY613561), P-endosymbiont of Diocalandra frumenti (AY126633), Rickettsia sp. (U76910) BLO causative agent of papaya bunchy top disease (9), S-endosymbiont of blood-sucking tsetse fly Glossina brevipalpis (U64870), Serratia marcescens (AB061685), Xenorhabdus nematophilus (Z76738), and unidentified bacteria of host Drosophila paulistorum (Diptera) (U20279).

\section{RESULTS}

PCR amplification of 16S rDNA. The PCR products obtained by using fD1-Fra4 and Fra5-rP1 primer pairs with DNA sample templates listed in Table 1 are shown in Figure 1A and B. Amplification products of the expected size were obtained with positivecontrol DNA from strawberry infected with 'Candidatus Phlomobacter fragariae' using fD1-Fra4 (976 bp) and Fra5-rP1 (1,040 bp) (Fig. 1A and B, lane 21). Similar products were obtained from SBR-affected sugar beet plants from the fields, from Pentastiridius sp.-exposed seedlings showing SBR symptoms, and from feral Pentastiridius sp. planthoppers (Fig. 1A and B, lanes 1 to 4, 7 to 12 , and 13 to 20 , respectively). No PCR products were ob- tained with DNA from sugar beet controls (i.e., field-collected symptomless sugar beet and healthy seedling) (Fig. 1A and B, lanes 5 and 6, respectively) or from the water control (Fig. 1A and B, lane 22), regardless of the procedure used.

PCR assay for amplification of nonribosomal Pfr1-Pfr4 DNA fragment. PCR products obtained using Pfr1-Pfr4 primers are shown in Figure 1C. An amplification product of the expected size (895 bp) was obtained with positive-control DNA from strawberry infected with 'Candidatus Phlomobacter fragariae' (Fig. 1C, lane 21). No amplification was obtained with DNA from any of the sugar beet plants or Pentastiridius specimens tested (Fig. 1C, lanes 1 to 4 and 7 to 20), with DNA from sugar beet controls (Fig. 1C, lanes 5 and 6), or from the water control (Fig. 1C, lane 22).

Nucleotide sequence analysis. The fD1-Fra4 and Fra5-rP1 PCR products from 10 plant and 8 insect samples (Fig. 1A and B) were sequenced. Both overlapping sequences (fD1-Fra4 and Fra5rP1) of each sample were assembled to obtain the corresponding fD1-rP1 fragment (Fig. 2, SBR BLO). After multiple sequence alignment analysis of the fD1-rP1 fragment (1,507 bp), $100 \%$ identity was found between all sequences obtained from plants and from Pentastiridius sp. Sequence analyses confirmed that this sequence was part of the 16S rRNA gene of the SBR BLO. Several identifying signature sequences of the $\gamma-3$ subgroup of proteobacteria were found within the nucleotide sequence obtained (Fig. 2) (26). The sequence of the fD1-rP1 16S rDNA frag-

TABLE 2. GenBank sequences orthologous to $16 \mathrm{~S}$ ribosomal DNA of "basses richesses" (SBR) proteobacteria and information on bacteria and their insect hosts

\begin{tabular}{|c|c|c|c|c|c|}
\hline Bacterial name ${ }^{a}$ & $\begin{array}{l}\text { Accession } \\
\text { no. }\end{array}$ & $\begin{array}{l}\text { Identity } \\
(\%)^{\mathrm{b}}\end{array}$ & Status ${ }^{c}$ & Host information & Hosts of insect \\
\hline Ars end of Acanthaleyrodes styraci & AY264663 & 98.82 & Facultative & Whitefly & Rubus reflexus \\
\hline Ars end of Aleurodicus dispersus & AY264664 & 96.19 & Facultative & Whitefly, pest & Palm \\
\hline Ars end of Aleurodicus dugesii & AY587142 & 97.82 & nd & Whitefly, pest and virus vectors & $\begin{array}{l}\text { Begonia, hibiscus, giant bird of paradise, } \\
\text { orchid tree, banana, mulberry, } \\
\text { vegetables, and many ornamentals }\end{array}$ \\
\hline Ars end of Aleuroplatus gelatinosus & AY264665 & 99.18 & Facultative & Whitefly & Te black oak group of Quercus \\
\hline Ars end of Aleyrodes elevatus & AY264666 & 99 & Facultative & Whitefly, pest & Ficus carica \\
\hline Ars end of Aleyrodes proletella & AY587141 & 97.73 & nd & Whitefly, pest & Brassica sp. \\
\hline Ars end of Bemisia sp. & AY264677 & 95.1 & Facultative & Whitefly, pest and virus vectors & Bocconia sp. \\
\hline Ars end of Dialeurodes hongkongensis & AY264667 & 98.73 & Facultative & Whitefly & Dendrotrophe frutescens \\
\hline Ars end of Neomaskellia andropogonis & AY264668 & 98.82 & Facultative & Whitefly & Saccharum sp. ontaneum \\
\hline Ars end of Siphoninus phillyreae & AY264669 & 97 & Facultative & Whitefly & $\begin{array}{l}\text { Many broadleaved trees and shrubs } \\
\text { including ash, citrus, Bradford, ring } \\
\text { fruit trees, pomegranate, redbud, toyon }\end{array}$ \\
\hline Ars end of Tetraleurodes acaciae & AY264670 & 98.91 & Facultative & Whitefly, pest & Erythrina sp. eciosa \\
\hline Ars end of Tetraleurodes mori & AY264671 & 95.96 & Facultative & Whitefly & Arbutus menziesii \\
\hline Ars end of Trialeurodes hutchingsi & AY587140 & 98.36 & nd & Whitefly & Manzanita \\
\hline Ars end of Trialeurodes vaporariorum & AY264672 & 98.55 & Facultative & Whitefly, pest & $\begin{array}{l}\text { Very broad including most vegetables } \\
\text { and herbaceous ornamentals }\end{array}$ \\
\hline Eubacterium from Aleurodicus dugesii & AF286129 & 95.82 & nd & Whitefly, pest and virus vectors & $\ldots$ \\
\hline Sec end of Bemisia tabaci clone UG2 & AF400481 & 98 & Facultative & Whitefly, pest and virus vectors & $\ldots$ \\
\hline Ars end of Diaphorina citri & $\mathrm{AB} 038366$ & 99 & nd & Psyllid, Huanglongbing vector & Citrus sp. \\
\hline Sec end of Glycaspis brimblecombei & AF263561 & 98.91 & Facultative & Psyllid, pest & Eucalyptus camaldulensis \\
\hline Sec end of Heteropsylla texana & AF263562 & 98.45 & Facultative & Psyllid, pest & Propsopis velutiana \\
\hline Symbiont of Myzocallis sp. & AY136153 & 98.45 & Facultative & Aphid, pest & Quercus peduncularis \\
\hline Symbiont of Wahlgreniella nervata & AY136168 & 99.36 & Facultative & Aphid, pest & Rose \\
\hline Ars end of Australiococcus greville & AY264673 & 99.18 & Facultative & Mealybug, pest & Grevillea $\mathrm{sp}$ \\
\hline Candidatus Arsenophonus insecticola & DQ115536 & 99.27 & Facultative & $\begin{array}{l}\text { Intracellular sec end from the } \\
\text { hippoboscid louse-fly }\end{array}$ & Ectoparasites of birds \\
\hline Ars end of Dermacentor variabilis & AY265347 & 96.73 & nd & $\begin{array}{l}\text { Tick, pest, vector of Rocky } \\
\text { mountain spotted fever }\end{array}$ & Dogs in North America \\
\hline Arsenophonus nasoniae & M90801 & 96.36 & $\mathrm{x}$ & $\begin{array}{l}\text { Wasp, causative agent of the son- } \\
\text { killer trait in Nasonia vitripennis }\end{array}$ & Parasitoid wasp of various fly species \\
\hline Arsenophonus triatominarum & U91786 & 97.91 & $\mathrm{x}$ & $\begin{array}{l}\text { Triatoma infestans bug, vector } \\
\text { of Chagas diseases }\end{array}$ & $\begin{array}{l}\text { Nocturnal predator that blood feeds on } \\
\text { mammals while they are asleep }\end{array}$ \\
\hline Candidatus Phlomobacter fragariae & U91515 & 97.64 & $\mathrm{x}$ & Cixius wagneri, planthopper & $\begin{array}{l}\text { Tall herbs, various deciduous trees, } \\
\text { strawberry, shrubs }\end{array}$ \\
\hline
\end{tabular}


ment of the SBR proteobacteria $(54 \% \mathrm{C}+\mathrm{G})$ has been deposited in the GenBank database as accession number AY057392.

Several orthologous sequences from other insect-associated bacteria were found in the GenBank database by BLAST analysis. These organisms showed sequence similarities ranging from 95 to $99.3 \%$ with the partial $16 \mathrm{~S}$ rDNA of the SBR proteobacteria (Table 2). Several of these bacteria have been described as facultative insect endosymbionts (Table 2).

The fD1-rP1 16S rDNA fragment of the SBR proteobacteria shared $97.64 \%$ identity with the $16 \mathrm{~S}$ rDNA sequence from 'Candidatus Phlomobacter fragariae' (Table 2). The two 16S rDNA fragments also differed by a 36-bp deletion (position 64 to 99) in the $16 \mathrm{~S}$ rDNA sequence from 'Candidatus Phlomobacter fragariae' (Fig. 2, SBR BLO and CPF). This sequence deletion was not observed in the 16S rDNA from the other $\gamma-3$ proteobacteria closely related to the SBR proteobacteria (Table 2; Fig. 2).

Phylogenetic analysis. Results of phylogenetic analysis by neighbor-joining method (on 0.569 evolutionary distance) based on comparisons of a 1,220-bp 16S rDNA sequence (AY057392) of SBR proteobacteria and $\gamma$-proteobacteria sequences obtained from GenBank are presented in Figure 3A. 'Candidatus Portiera aleyrodidarum' was chosen as an outgroup. An evolutionary framework of Hemiptera insects that showed a relationship to the bacteria listed in Figure 3A is shown in Figure 3B.

SBR proteobacteria clustered in a monophyletic group $(100 \%$ bootstrap value). All bacteria contained in this clade were de- scribed as endosymbionts of insects or found in insects (Table 2) and most belonged to the genus Arsenophonus (Table 2; Fig. 3).

Many hosts of related bacteria were hemipterans (Fig. 3B) and included representatives of four Hemiptera suborders (Sternorrhyncha, Fulgoromorpha, Cicadomorpha, and Heteroptera) (4). Several hosts of bacteria clustering in the same clade as SBR proteobacteria were Sternorrhyncha: Psylloidea (psyllids), Aleyrodoidea (whiteflies), Aphidoidea (aphids), and Coccoidea (Mealybug) (Table 2; Fig. 3). To simplify Figure 3, only 1 among the 16 closely related whitefly endosymbionts, the Arsenophonus endosymbiont of Aleuroplatus gelatinosus (AY264665), and 1 among 3 closely related psyllid endosymbionts, secondary endosymbiont of Diaphorina citri (AB038366) (Table 2), were included in the phylogenetic study (Fig. 3). All clustered in the same clade (data not shown). Many bacteria present in the clade were described as facultative insect endosymbionts (Table 2).

Other proteobacteria present in the same clade are 'Candidatus Arsenophonus insecticola,' an intracellular secondary endosymbiont from the louse-fly (Diptera: Hippoboscidae), and bacteria isolated from insects but not described as endosymbionts: Arsenophonus nasoniae, isolated from the wasp Nasonia vitripennis (Hymenoptera: Pteromalidae); A. triatominarum, isolated from the triatomine bug Triatoma infestans (Heteroptera: Triatominae), vector of Chagas disease; and 'Candidatus Phlomobacter fragariae', transmitted by Cixius wagneri (Hemiptera: Cixiidae). The SBR proteobacteria is the second described plant-pathogenic bacteria in this clade, related to but distinct from 'Candidatus Phlomo-

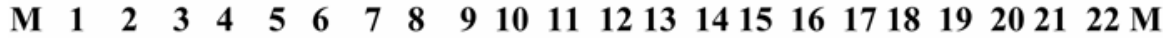
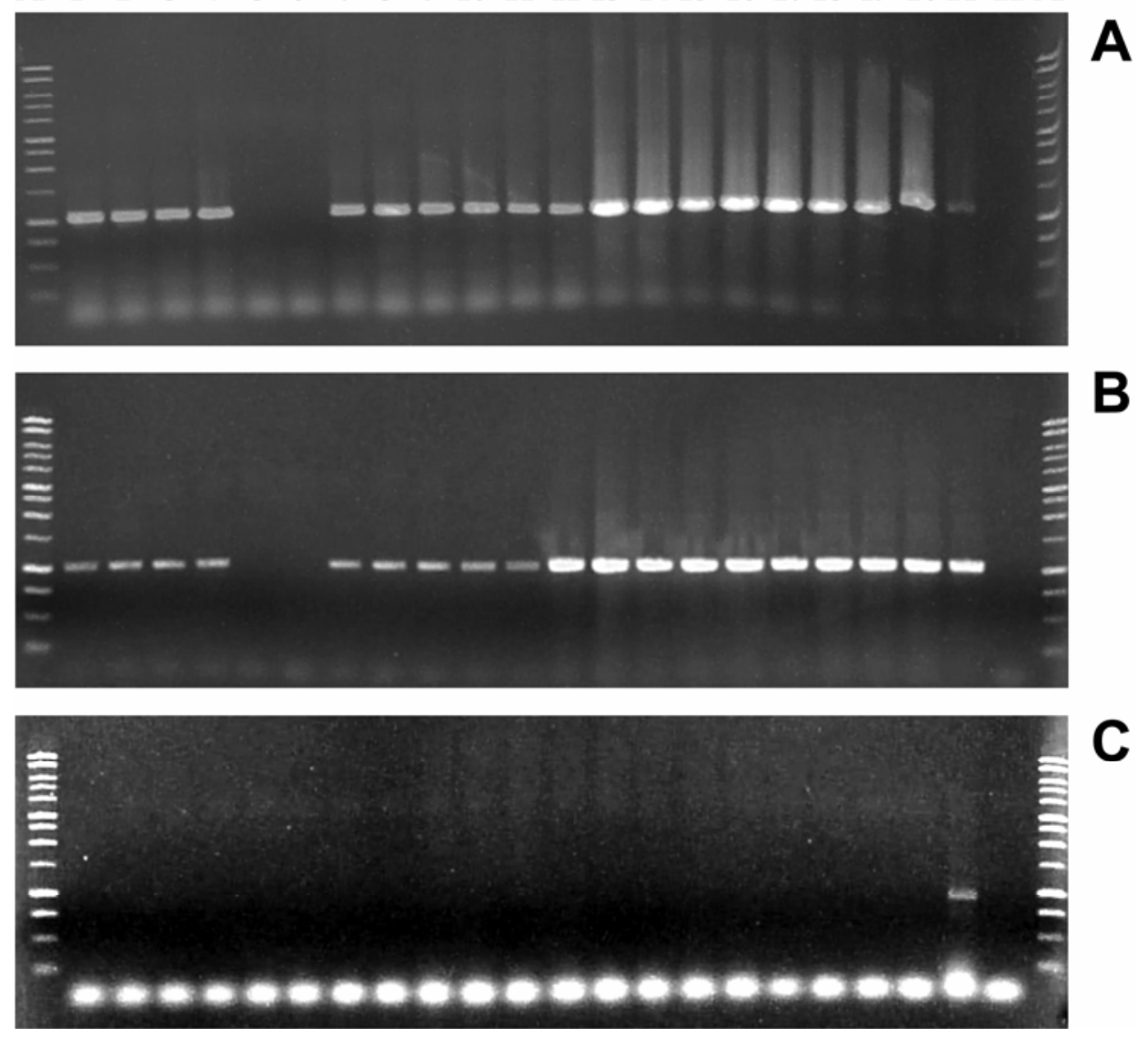

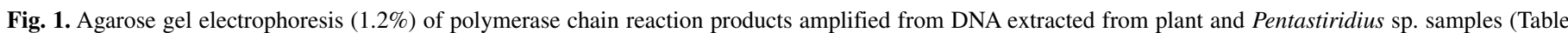

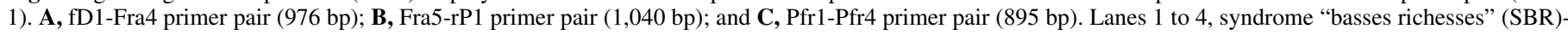

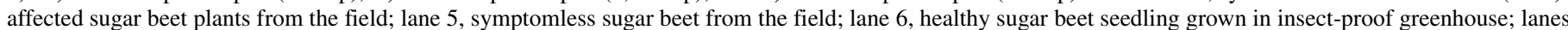

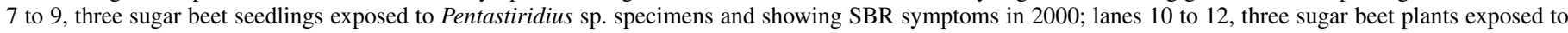

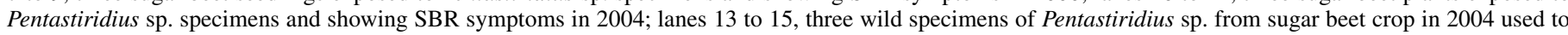

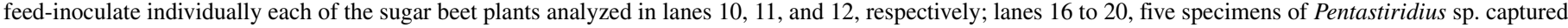

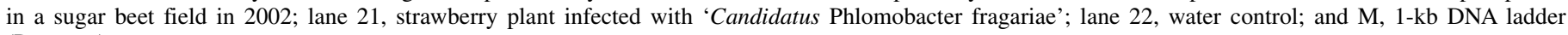
(Promega). 
bacter fragariae', the agent of marginal chlorosis of strawberry. Both bacteria also were found in the same insect family of Cixiidae.

Other Hemiptera endosymbionts or bacteria isolated from Hemiptera also are present among $\gamma$-proteobacteria: a bacterial parasite of Euscelidius variegatus (Hemiptera: Cicadellidea), and Baumannia cicadenillinicola, an endosymbiont of the xylemsucking sharpshooter Homalodisca coagulata (Hemiptera: Cicadoidea), vector of Pierce's disease.

\section{DISCUSSION}

The SBR is a new and important disease of sugar beet. It is associated with either of two phloem-restricted pathogenic agents: a stolbur phytoplasma or, more frequently, BLO. Both are transmitted by the same vector insect, a cixiid in the genus Penta- stiridius that could be observed in high populations in sugar beet fields (13). Transmission experiments to sugar beet with feral planthoppers and leafhoppers of different species did not demonstrate vectors of SBR other than Pentastiridius sp. (O. Sémétey, unpublished data). Another plant disease in France, marginal chlorosis of strawberry, also is associated with a phytoplasma or a plant-pathogenic $\gamma-3$ proteobacteria, 'Candidatus Phlomobacter fragariae.' The latter was shown to be transmitted also by a cixiid planthopper, Cixius wagneri (6).

In this article, we amplified a 1,507-bp 16S rDNA fragment of the BLO from phytoplasma-free symptomatic sugar beet plants in which BLO was visualized in phloem sieve tube elements with DAPI. BLO belongs to the $\gamma$-proteobacteria, as revealed by analysis of a 16S rDNA region (GenBank AY057392) which included several sequence signatures of the $\gamma-3$ subgroup of proteobacteria.

\begin{abstract}
fD1 (forward)
SBR BLO AGAGTTTGATCCTGGCTCAGATTGAACGCTGGCGGCAGGCCTAACACATGCAAGTCGAGCGGCAGCGGGAGGAAGCTTGCTTCCTTGCCGGCGAGCGGCGGACGGGTGAGTAAGGTATGG 120

AeA $\quad \begin{array}{ll}\text { APf } \\ n\end{array}$

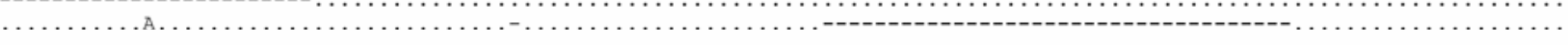

SBR BLO GGATCTGGCCAAAGGGGGGGATAACCACTGGAAACGGTGGCTAATACCGCATAATCTCTAAGGAGCAAAGTGGGGGACCGTTCTGGCCTCACACCTTCGGATGAACCCATATGAGATTA 240

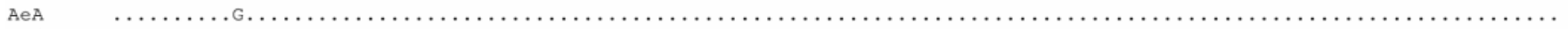

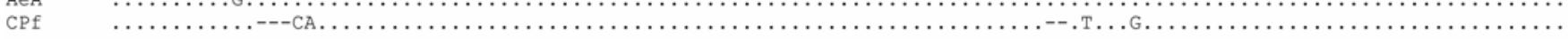

SBR BLO GCTAGTAGGTGGGGTAAGGGCTCACCTAGGCGACGATCTCTAGCT--GGTCTGAGAGGATGATCAGCCACACTGGGACTGAGACACGGCCCAGACTCCTACGGGAGGCAGCAGTGGGGAA 358

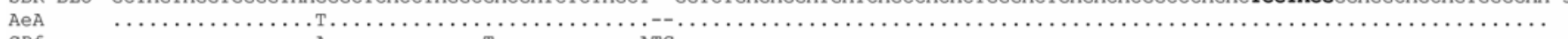

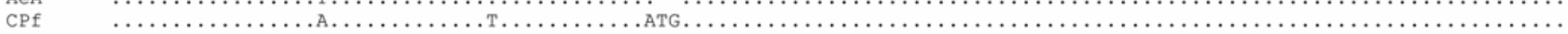

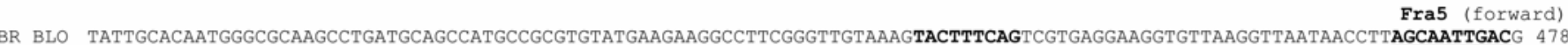

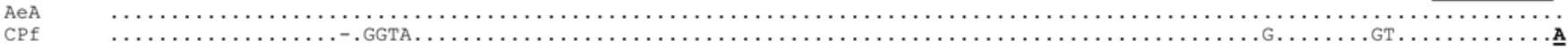

SBR BLO TTAGCGACAGAAGAAGCACCGGCTAACTCCGTGCCAGCAGCCGCGGTAATACGGAGGGTGCGAGCGTTAATCGGAATTACTGGGCGTAAAGGGCACGCAGGCGGTTAATTAAGTTGGATG 598

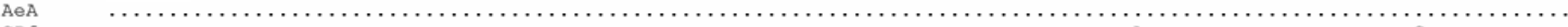

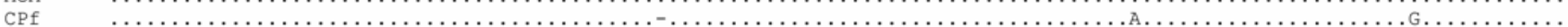

SBR BLO TGAAATCCCCGGCTTAACCTGGGAATGGCATTCAAGACTGGTTAGCTAGAGTCTTGTAGAGGGGGCAGAATTCCATGTGTAGCGGTGAAATGCGTAGAGATGTGGAGGAATACCGGTG 718

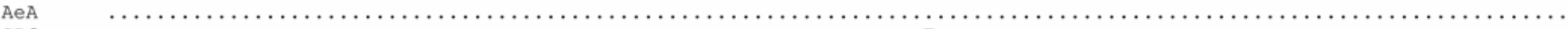

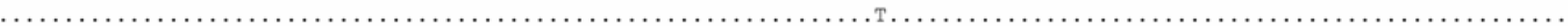

SBR BLO GCGAAGGCGGCCCCTGGACAAA-GACTGACGCTCATGTGCGAAAGCGTGGGGAGCAAACAGGATTAGATACCCTGGTAGTCCACGCTGTAAACGATGTCGATTTGGAGGTTGTGGTCAT 837

Fra4 (reverse)

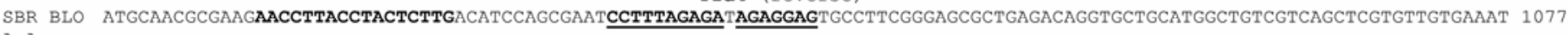

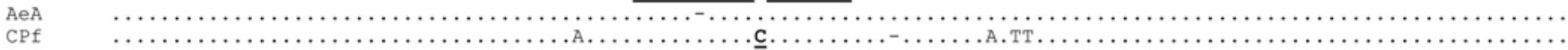

SBR BLO GTTGGGTTAAGTCCGCAACGAGCGCAACCCTTATCCTTTGTTGCCAGCGAGTAGAGTCGGGAACTCAAAGGAGACTGCCGGTGATAAACCGGAGGAAGGTGGGGATGACGTCAAGTCAT 1197

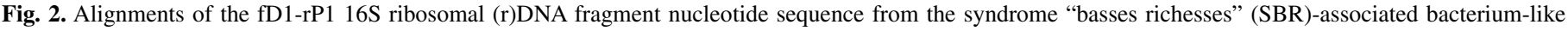

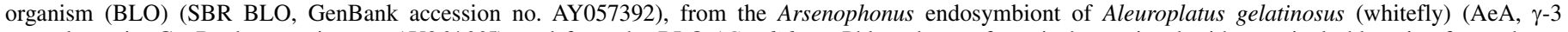

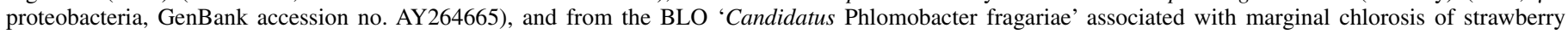

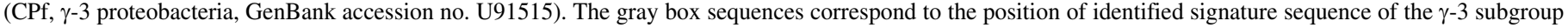

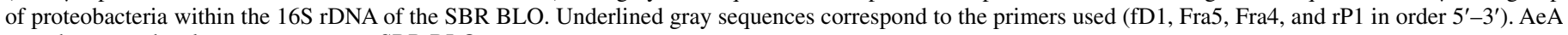
was chosen as the closest sequences to SBR BLO.
\end{abstract}


SBR proteobacteria were found in SBR-affected sugar beet plants from the field, in symptom-bearing sugar beet plants inoculated with Pentastiridius sp., and in Pentastiridius sp. planthoppers trapped in sugar beet fields and used for inoculation experiments. Plants and insects used in the study were collected in different fields and regions and in different years. Our data confirmed the association of SBR BLO with SBR symptoms in sugar beet and also the vector role of Pentastiridius sp. in the epidemiology of SBR disease. No nucleotide sequence variation was observed in the 1,507-bp $16 \mathrm{~S}$ rDNA fragment of the SBR bacteria among strains from different hosts, years, or regions of collection. This strongly suggests that the BLO involved in SBR is a unique bacterium.

SBR proteobacterium and 'Candidatus Phlomobacter fragariae' are, up until now, the only two characterized phloem-restricted plant-pathogenic $\gamma-3$ proteobacteria and both are transmitted by planthoppers (Hemiptera, Fulgoromorpha, Cixiidae). When comparisons were made on the basis of 16S rDNA sequence, both bacteria clustered together in the same clade and they shared 97.64\% sequence identity. In addition, no products were amplified from the DNA template of SBR-affected plants and Pentastiridius sp. specimens using the nonribosomal primers Pfr1-Prf4 used to detect 'Candidatus Phlomobacter fragariae' (10). These results suggest that the two bacteria are related but distinct. Two other bacteria described as plant-pathogenic BLOs were found among $\gamma$-proteobacteria but without close relationship with SBR proteobacteria. These are Serratia marcescens (phloem-restricted BLO associated with the yellow vine disease of watermelon) (2) and the rickettsia-like bacterium associated with papaya bunchy top disease (8).
Phylogenetic analysis showed that SBR proteobacterium is monophyletic with 27 bacteria analyzed, most of which belong to the genus Arsenophonus, first described for Arsenophonus nasoniae, a bacterium causing male egg mortality in the parasitoid wasp Nasonia vitripennis (14). Many hosts of $\gamma$-proteobacteria are insects, mainly sap-sucking Hemiptera. In particular, several Sternorrhyncha endosymbionts are present in the same monophyletic clade as SBR proteobacteria.

Many bacteria within the clade were described as secondary insect endosymbionts (S-endosymbionts) (facultative bacteria) $(3,11,20)$. Recent studies implicated S-endosymbionts in insect resistance to parasitoid infection or in its recovery from heat stress $(16,17)$. These S-endosymbionts differ from obligatory bacteria called primary endosymbionts (P-endosymbionts). A function of P-endosymbionts is the synthesis of amino acids which are utilized by their hosts and counterbalance plant sap deficiency (25). We included two of them in the phylogenetic analyses: 'Candidatus Carsonella ruddii' (P-endosymbiont of psyllid) (21) and 'Candidatus Portiera aleyrodidarum' (P-endosymbiont of whitefly) $(5,22)$. These P-endosymbionts clustered in a separate branch from S-endosymbionts of the same insect families, according to Thao and Baumann $(12,22)$. The close relationship shown on the basis of sequence identity and tree analysis between SBR proteobacteria and S-endosymbionts of insects, mostly Hemiptera, suggest that SBR proteobacteria could have a secondary endosymbiotic function in its vector insect. Nevertheless, no endosymbiotic bacteria have been described previously in association with Cixiidae.

The fact that SBR proteobacteria and 'Candidatus Phlomobacter fragariae' are mutually related, closely related to endo-

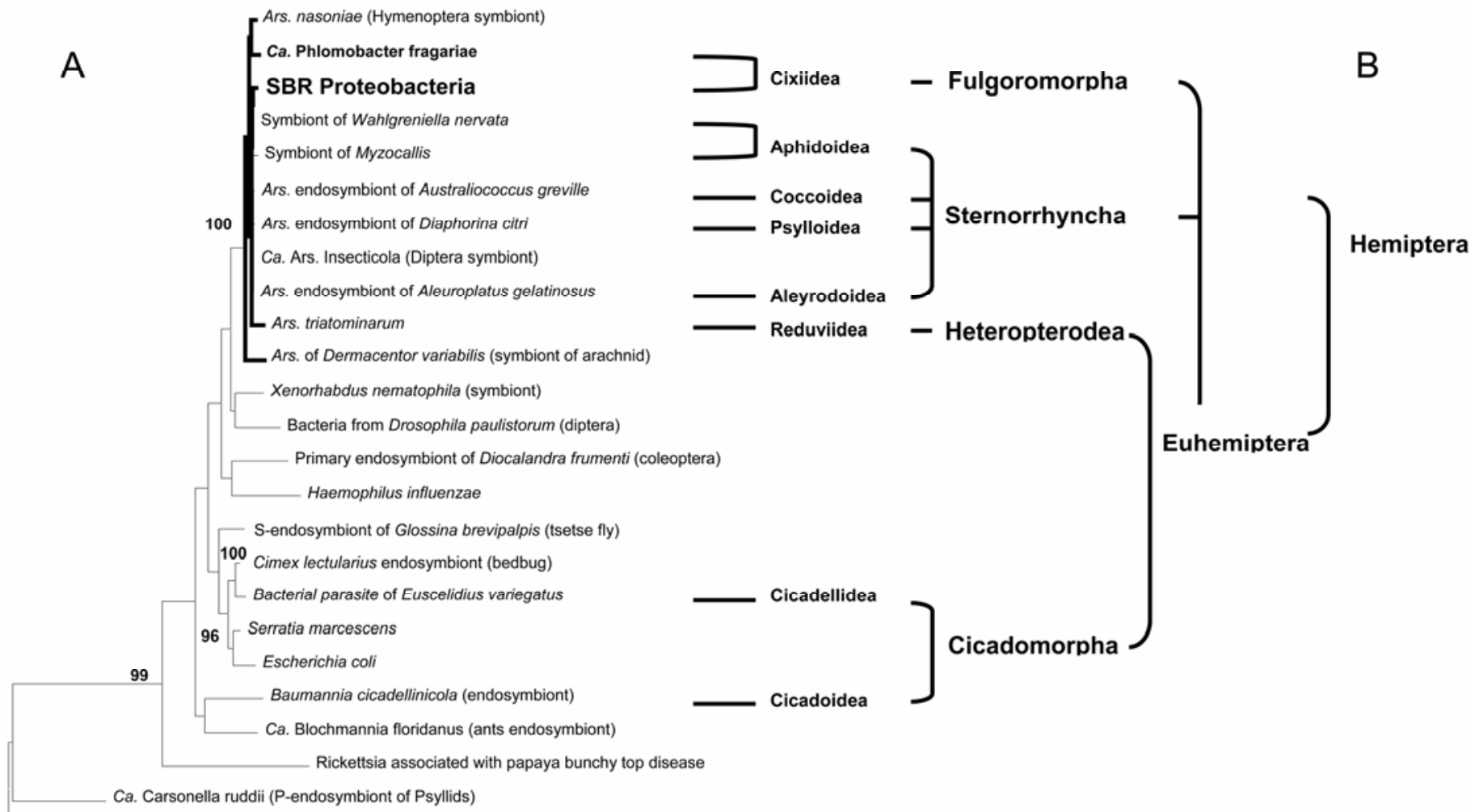

Ca. Portiera (P-endosymbionts of whiteflies)

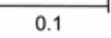

Fig. 3. A, Phylogenetic relationship between $16 \mathrm{~S}$ ribosomal (r)DNA sequence from the syndrome "basses richesses" (SBR) proteobacteria (AY057392) and 16S rDNA sequences from organisms obtained from GenBank, associated with B, the classification of Hemiptera insects based on 18S rDNA. The tree was constructed using the neighbor-joining method based on the 16S rDNA sequences. The analysis included the orthologous sequence of the $\gamma$-proteobacteria close to SBR proteobacteria. 'Candidatus Portiera aleyrodidarum' (AY268082) was defined as the outgroup for the phylogenetic tree construction. Length of horizontal lines for the Hemiptera phylogeny is arbitrary. The abbreviations Ca. for Candidatus and Ars. for Arsenophonus were used. The bar corresponds to $0.1 \%$ substitution for the bacteria phylogeny. 
symbionts of other hemipterans and transmitted by cixiids, suggests that endosymbiotic origin of the SBR proteobacteria in Pentastiridius sp. is more likely than a recent horizontal acquisition from other hemipterans (23). A histological study is underway to compare their localization and their organization to those of endosymbiotic bacteria. Also, specific PCR tools for detection of SBR proteobacteria in insects are under development to search for alternative vectors, study the SBR pressure in fields, and compare the SBR proteobacteria to the most closely related insect endosymbionts in order to clarify its status in Pentastiridius sp.

\section{ACKNOWLEDGMENTS}

This work was supported by the Institut technique français de la betterave industrielle and the Conseil Régional de Bourgogne. We thank G. Aubert for advice in phylogenetic analysis and $\mathrm{H}$. Charles and $\mathrm{X}$. Foissac for assistance in editing of the manuscript.

\section{LITERATURE CITED}

1. Altschul, S. F., Madden, T. L., Schaeffer, A. A., Zhang, J., Zhang, Z., Miller, W., and Lipman, D. J. 1997. Gapped BLAST and PSI-BLAST: A new generation of protein database search programs. Nucleic Acids Res. 25:3389-3402.

2. Avila, F. J., Bruton, B. D., Fletcher, J., Sherwood, J. L., Pair, S. D., and Melcher, U. 1998. Polymerase chain reaction detection and phylogenetic characterization of an agent associated with yellow vine disease of cucurbits. Phytopathology 88:428-436.

3. Baumann, L., Thao, M. L. L., Funk, C. J., Falk, B. W., Ng, J. C. K., and Baumann, P. 2004. Sequence analysis of DNA fragments from the genome of the primary endosymbiont of the whitefly Bemisia tabaci. Curr. Microbiol. 48:77-81.

4. Bourgoin, T., Steffen-Campbell, J. D., and Campbell, B. C. 1997. Molecular phylogeny of Fulgoromorpha (Insecta, Hemiptera, Archaeorrhyncha). The enigmatic Tettigometridae: Evolutionary affiliations and historical biogeography. Cladistic 13:207-224.

5. Charles, H., Heddi, A., and Rahbe, Y. 2001. A putative insect intracellular endosymbiont stem clade, within the Enterobacteriaceae, inferred from phylogenetic analysis based on a heterogeneous model of DNA evolution. C. R. Acad. Sci. Ser. 3 324:489-494.

6. Danet, J. L., Foissac, X., Zreik, L., Salar, P., Verdin, E., Nourrisseau, J. G., and Garnier, M. 2003. 'Candidatus Phlomobacter fragariae' is the prevalent agent of marginal chlorosis of strawberry in French production fields and is transmitted by the planthopper Cixius wagneri (China). Phytopathology 93:644-649.

7. Danet, J. L., Salar, P., Batailler, B., Foissac, X., and Garnier, M. 2004. Marginal chlorosis of strawberry: Transmission of 'Candidatus Phlomobacter fragariae' to periwinkle by the planthopper Cixius wagneri (China) and characterization of the isolate. Acta Hortic. 656:87-92.

8. Davis, M. J., Kramer, J. B., Ferwerda, F. H., and Brunner, B. R. 1996. Association of a bacterium and not a phytoplasma with papaya bunchy top disease. Phytopathology 86:102-109.

9. Davis, M. J., Ying, Z., Brunner, B. R., Pantoja, A., and Ferwerda, F. H. 1998. Rickettsial relative associated with papaya bunchy top disease. Curr. Microbiol. 36:80-84.

10. Foissac, X., Danet, J. L., Zreik, L., Gandar, J., Nourrisseau, J. G., Bové, J. M., and Garnier, M. 2000. Cloning of the spoT gene of 'Candidatus
Phlomobacter fragariae' and development of a PCR-restriction fragment length polymorphism assay for detection of the bacterium in insects. Appl. Environ. Microbiol. 66:3474-3480.

11. Fukatsu, T., Nikoh, N., Kawai, R., and Koga, R. 2000. The secondary endosymbiotic bacterium of the pea aphid Acyrthosiphon pisum (Insecta: Homoptera). Appl. Environ. Microbiol. 66:2748-2758.

12. Gatineau, F., Jacob, N., Vautrin, S., Larrue, J., Lherminier, J., RichardMolard, M., and Boudon-Padieu, E. 2002. Association with the syndrome "basses richesses" of sugar beet of a phytoplasma and a bacterium-like organism transmitted by a Pentastiridius sp. Phytopathology 92:384-392.

13. Gatineau, F., Larrue, J., Clair, D., Lorton, F., Richard-Molard, M., and Boudon-Padieu, E. 2001. A new natural planthopper vector of stolbur phytoplasma in the genus Pentastiridius (Hemiptera: Cixiidae). Eur. J. Plant Pathol. 107:263-271.

14. Gherna, R. L., Werren, J. H., Weisburg, W. G., Cote, R., Woese, C. R., Mandelco, L., and Brenner, D. J. 1991. Arsenophonus nasoniae gen. nov., sp. nov., the causative agent of the son-killer trait in the parasitic wasp Nasonia vitripennis. Int. J. Syst. Bacteriol. 41:563-565.

15. Higgins, D. G., and Sharp, P. M. 1988. CLUSTAL: A package for performing multiple sequence alignment on a microcomputer. Gene 73:237-244.

16. Montllor, C. B., Maxmen, A., and Purcell, A. H. 2002. Facultative bacterial endosymbionts benefit pea aphids Acyrthosiphon pisum under heat stress. Ecol. Entomol. 27:189-195.

17. Oliver, K. M., Russell, J. A., Moran, N. A., and Hunter, M. S. 2003. Facultative bacterial symbionts in aphids confer resistance to parasitic wasps. Proc. Natl. Acad. Sci. USA 100:1803-1807.

18. Richard-Molard, M., Garressus, S., Malatesta, G., Orny, G., Valentin, P., Reinbold, C., Gerst, M., Blech, F., Fonne, G., Putz, C., Grousson, C., and Boudon-Padieu, E. 1995. Le syndrome des basses richesses-investigations au champ et tentatives d'identification de l'agent pathogène et du vecteur. Pages 299-309 in: Proc. 58th Int. Inst. Beet Res. Congr. DijonBeaune, France.

19. Sudhir Kumar, K. T., Jakobsen, I. B., and Masatoshi, N. 2001. MEGA2: Molecular evolutionary genetics analysis software. Bioinformatics 17: 1244-1245.

20. Thao, M. L. L., Clark, M. A., Baumann, L., Brennan, E. B., Moran, N. A., and Baumann, P. 2000. Secondary endosymbionts of psyllids have been acquired multiple times. Curr. Microbiol. 41:300-304.

21. Thao, M. L. L., Moran, N. A., Abbot, P., Brennan, E. B., Burckhardt, D. H., and Baumann, P. 2000. Cospeciation of psyllids and their primary prokaryotic endosymbionts. Appl. Environ. Microbiol. 66:2898-2905.

22. Thao, M. L. L., and Baumann, P. 2004. Evidence for multiple acquisition of Arsenophonus by whitefly species (Sternorrhyncha: Aleyrodidae). Curr. Microbiol. 48(2):140-144.

23. Vega, F. E., Davis, R. E., Barbosa, P., Dally, E. L., Purcell, A. H., and Lee, I. M. 1993. Detection of a plant pathogen in a nonvector insect species by the polymerase chain reaction. Phytopathology 83:621-624.

24. Weisburg, W. G., Barns, S. M., Pelletier, D. A., and Lane, D. J. 1991. 16S ribosomal DNA amplification for phylogenetic study. J. Bacteriol. 173:697-703.

25. Wernegreen, J. J. 2002. Genome evolution in bacterial endosymbionts of insects. Nat. Rev. Genet. 3:850-861

26. Woese, C. R., Weisburg, W. G., Hahn, C. M., Paster, B. J., Zablen, L. B., Lewis, B. J., Macke, T. J., Ludwig, W., and Stackebrant, E. 1985. The phylogeny of purple bacteria: The gamma subdivision. System. Appl. Microbiol. 6:25-33.

27. Zreik, L., Bové, J. M., and Garnier, M. 1998. Phylogenetic characterization of the bacterium-like organism associated with marginal chlorosis of strawberry and proposition of a Candidatus taxon for the organism, 'Candidatus Phlomobacter fragariae'. Int. J. Syst. Bacteriol. 48:257-261. 